\title{
Konya İlinde Yetiştirilen Patates Yumrularında Lastik Çürüklük Hastalık Etmeni Geotrichum candidum’un İzolasyonu, Morfolojik ve Moleküler Karakterizasyonu
}

\author{
Soner SOYLU ${ }^{\&}$, Merve KARA2, Osman TOKETTİ ${ }^{3}$, E. Mine SOYLU ${ }^{4}$, Aysun UYSAL ${ }^{5}$, Şener KURT6 \\ 1,2,3,4,6Hatay Mustafa Kemal Üniversitesi, Ziraat Fakültesi, Bitki Koruma Bölümü 31034 Antakya-HATAY, ${ }^{5}$ Hatay Mustafa Kemal \\ Üniversitesi, Bitki Sağlığı Kliniği Uygulama ve Araştırma Merkezi, 31034 Antakya-HATAY \\ ${ }^{1}$ https://orcid.org/0000-0003-1002-8958, ${ }^{2}$ https://orcid.org/0000-0001-7320-3376, ${ }^{3}$ https://orcid.org/0000-0001-8955-2132, \\ ${ }^{4}$ https://orcid.org/0000-0001-5961-0848, ${ }^{5}$ https://orcid.org/0000-0002-9067-285X, 6https://orcid.org/0000-0003-4545-5968, \\ $\bowtie$ : soylu@mku.edu.tr
}

\section{ÖZET}

Patates (Solanum tuberosum L.), Türkiye'de en fazla tüketilen sebzelerin başında gelmektedir. Konya ilinin Çumra ilçesinde 2019 yılının Temmuz ayında patates yetiştirilen alanlarda gerçekleştirilen sörveyler sırasında ekşi koku yayan patates yumrularında beyaz miselyum ile kaplanmış suya batırılmış yumuşak lastik çürüklük lezyonları şeklinde yeni hastalık belirtileri gözlenmiştir. Yüzey dezenfeksiyonu yapılan enfekteli yumrulardan alınan dokular Patates Dekstroz Agar (PDA) besiyeri üzerine yerleştirilmiş ve $25^{\circ} \mathrm{C}$ 'de inkübasyona bırakılmıştır. Enfekteli dokulardan hızlı büyüyen beyaz, düz ve süetimsi-tozlu görünümlü pigmentsiz fungal koloniler gelişmiştir. Gelişen kolonilerin miselyumları dichotomous olarak dallanmış, şeffaf ve bölmeli yapıda olup, hiflerden oldukça farklı boyutlarda şeffaf, tek hücreli ve silindirik yapıda havai artrokonidilerin geliştiği gözlenmiştir. Fungal etmenin kültürel ve morfolojik özellikleri Geotrichum candidum ile tutarlıdır. Yapay inokulasyon yapılan patates yumruları üzerinde doğal enfekteli patates yumrularında görülen belirtilerin benzeri gözlenmiş olup fungal etmen bu dokulardan yeniden izole edilmiştir. İzole edilen fungal etmenin morfolojik tanisı, Matrix Assisted Laser Desorption Ionization-Time of Flight Mass Spectrometry (MALDI-TOF MS) cihazı kullanarak protein profili ve Internal Transcribed Spacer (ITS) gen bölgesi (ITS1-5.8S rDNA-ITS4) çoğaltılıp dizilenmesi ile moleküler olarak da teyit edilmiştir. Gen bankasına kaydedilen temsili izolatın sekans sonucu G. candidum izolatı ile \%99 oranında benzerlik göstermiştir. G. candidum'un sebep olduğu patates lastik çürüklük hastalığının varlığı Türkiye'de önceden bildirilmemiştir. Türkiye'de yetiştirilen patates yumrularında lastik çürüklüğü hastalığı etmeni $G$. candidum'un morfolojik ve moleküler karakterizasyonu ilk kez bu çalışma ile ortaya konulmuştur.

\section{Araştırma Makalesi}

Makale Tarihçesi

Geliş Tarihi : 03.04.2020

Kabul Tarihi : 26.08 .2020

Anahtar Kelimeler
Patates
Lastik çürüklük
Geotrichum candidum
MALDI-TOF
ITS

Isolation, Morphological and Molecular Characterization of Rubbery Rot Disease Disease Agent Geotrichum candidum on Potato Tubers Grown in Konya Province

\section{ABSTRACT}

Potato is the one of the most consumed vegetable in Turkey. During field surveys in June of 2019 , new disease symptoms on potato tubers, displaying a water-soaked soft rubbery rot with a sour, fermented smell, and white mycelial growth, were observed in commercial fields in Çumra district of Konya, Turkey. Diseased tubers were collected and small tissue pieces from surface disinfected symptomatic tuber were placed on potato dextrose agar (PDA) and incubated at $25^{\circ} \mathrm{C}$. Fast growing, flat, white to cream, dry and finely suede-like with no reverse pigmented fungal colonies were subsequently developed from infected tissues. Hyphae were hyaline, dichotomously branched and septate, producing aerial chains of hyaline, smooth, one-celled, cylindrical arthroconidia. Cultural and morphological characters were
Research Article

$\begin{array}{ll}\text { Article History } & \\ \text { Received } & : 03.04 .2020 \\ \text { Accepted } & : 26.08 .2020\end{array}$

Keywords
Potato
Rubbery rot
Geotrichum candidum
MALDI-TOF
ITS


consistent with Geotrichum candidum. All artificially inoculated tubers displayed the same symptoms as seen for naturally infected tubers and the fungus having same morphological characters was reisolated from inoculated tubers. Morphological identification of disease agent was confirmed molecularly based on protein profiling by using MALDI-TOF MS and also by sequencing amplified Internal Transcribed Spacer (ITS) region ((ITS1-5.8S rDNA-ITS4). The sequence was $99 \%$ identical and a representative sequence of isolate was submitted to GenBank. The presence of potato rubbery rot disease caused by $G$. candidum has not been previously reported in Turkey. This is the first report of morphological and molecular characterization of $G$. candidum causal disease agent of rubber rot on potato tubers grown in Turkey.

$\begin{array}{ll}\text { Atıf İçin: } & \text { Soylu S, Kara M, Toketti O, Soylu EM, Uysal A, Kurt Ş 2021. Konya İlinde Yetiştirilen Patates Yumrularında } \\ & \text { Lastik Çürüklük Hastalı Etmeni Geotrichum candidum'un İzolasyonu, Morfolojik ve Moleküler } \\ & \text { Karakterizasyonu. KSÜ Tarım ve Doğa Derg 24 (2): 353-361. https://doi.org/10.18016/ksutarimdoga.vi.714056. } \\ \text { To Cite: } & \text { Soylu S, Kara M, Toketti O, Soylu EM, Uysal A, Kurt Ş 2021. Isolation, Morphological and Molecular } \\ & \text { Characterization of Rubbery Rot Disease Disease Agent Geotrichum candidum on Potato Tubers Grown in Konya } \\ & \text { Province. KSU J. Agric Nat 24 (2): 353-361. https://doi.org/10.18016/ksutarimdoga.vi.714056. }\end{array}$

\section{GİRIŞ}

Ana vatanı Güney Amerika'da yer alan Peru ve Şili olan patates (Solanum tuberosum L), insan beslenmesinde önemli bir yeri olan bir sebze türüdür. Solanum cinsine bağlı olan patates bitkisinin dünya genelinde 8 türünün tarımı ve üretimi yapılmaktadır. İngiltere'de en fazla tüketilen sebze olan patates, dünya genelinde ise misır, pirinç ve buğday'dan sonra 381.000.000 ton üretimi ile en fazla tüketilen 4. önemli tarım ürünüdür (Ezekiel ve ark., 2013; Zhang ve ark., 2017). Dünya Gıda Tarım Örgütünün (FAO) 2016 yılı dünya patates üretim istatistiklerine göre önemli patates üretimi yapan ilk 10 ülkelerin sırası ile Çin (99.065.00 ton), Hindistan (43.770.000 ton), Rusya (31.107.797 ton), Ukrayna (21.750.290 ton), ABD (19.990.950 ton), Almanya (10.772.100 ton), Bangladeş (9.474,099 ton), Polonya (8.872.000 ton), Fransa (6.834.680 ton) ve Hollanda (6.534.338 ton) olduğu bildirilmiştir (Anonymous, 2017). Türkiye'de en fazla patates üretimi 527.554 da alanla Orta Anadolu bölgesinde yapilırken, bu bölgeyi 276.641 da ile Ege, 147.257 da ile Batı Anadolu bölgeleri izlemiştir. Orta Anadolu bölgesinde Niğde (237.851 da alanda 892.297 ton) ve Nevşehir (58.856 da alanda 255.773 ton) illeri Türkiye'nin en fazla patates tarımının yapıldığı iller arasinda olup, bu illeri Afyon (139.956 da alanda 476.900 ton), Konya ( 135.824 da alanda 549.802 ton) ve İzmir (104.974 da alanda 367.706 ton) illeri takip etmektedir (Anonim, 2017).

Türkiye için önemli bir ürün olan patatesin üretimi, verimi ve kalitesi farkl türlere ait toprak kökenli fungal hastalık etmenleri tarafindan ciddi tehdit altındadır (Koike ve ark., 2007). Dünyanın önemli patates yetiştiriciliğinin yapıldığı ülkelerde olduğu gibi, Türkiye'de Fusarium sambucinum, Phytophthora cryptogea, Rhizoctonia solani, Sclerotinia sclerotiorum, Synchytrium endobioticum ve Verticillium dahliae gibi fungal etmenler patates üretimini kıstlayan en önemli toprak kökenli fungal hastalık etmenleri olarak bildirilmiştir (Çakır, 2005; Yanar ve ark., 2005; Çakır ve Demirci, 2012; Göre ve ark., 2015; Aydın ve ark., 2016; Kurt ve ark., 2017). Tarla koşullarında olduğu kadar, depolarda yer alan patates yumru örneklerinde Colletotrichum coccoides, $F$. sambucinum (Gibberella pulicaris), $F$. solani, $F$. culmorum, $F$. oxysporum ve Pythium ultimum etmenlerinin farklı patates çeşitleri üzerinde şiddetli hastalık belirtilerine neden oldukları bildirilmiştir (Eken ve ark., 2000; Özer ve ark., 2018; Çakır ve ark., 2019).

Bu çalışmada, Konya ilinin Çumra ilçesinde yapılan sörveyler sırasında karşılaşılan, yumrularda sulu ve yumuşak çürüklük şeklinde belirtilere neden olan hastalık etmeninin morfolojik, patolojik ve moleküler olarak tanılanması amaçlanmıştır.

\section{MATERYAL ve METOD}

Hastallk Etmeninin İzolasyonu, Morfolojik ve Patojenik Özelliklerinin Belirlenmesi

Hastalık etmeni, Konya ilinin Çumra İlçesinde hastalığın gözlendiği tarlalardan temin edilen 8 farklı hastalık belirtisi gösteren patates yumrularından izole edilmiştir. Bu amaçla, yumruların yarı hastalıklı ve yarı sağlam dokularından bistüri yardımıyla küçük parçalar kesilmiştir. Kesilen parçalar, \%2'lik sodyum hipoklorit $(\mathrm{NaOCl})$ solüsyonunda 2 dakika yüzey dezenfeksiyonu yapılıp steril saf su ile durulanmıştır. Dezenfekte edilen yumru dokuları steril kurutma kağıdına alınarak kurumaya bırakılmıştır. Kurumuş olan yumru parçaları petri kaplarındaki $100 \mu \mathrm{g} \mathrm{ml}{ }^{-1}$ streptomycin sulphate içeren Patates Dekstroz Agar (PDA, Merck, Darmstadt, Germany) besiyeri üzerine yerleştirilerek $25^{\circ} \mathrm{C}^{\prime}$ de 5-7 gün süre ile inkübasyona bırakılmıştır. PDA içeren petrilerde gelişen fungal kolonilerin tanısı morfolojik ve mikroskobik olarak 
gerçekleştirilmiştir (Kim ve ark., 2011). Fungus, tek spor izolasyon tekniği ile saflaştırılmıştır. Elde edilen tek spor izolatı, eğik tüp içerisinde PDA besiyerine alınmış ve $+4^{\circ} \mathrm{C}^{\prime}$ de saklanmıştır.

Spreyle püskürtme inokulasyon yönteminin kullanıldığı patojenisite denemeleri için, sağlıklı patates yumruları (cv. Lady Anna) kullanılmıştır. Patojenite testinde, PDA ortaminda 5-7 gün boyunca $25^{\circ} \mathrm{C}$ 'de inkübe edilen bölge izolatına ait kültürler kullanılmıştır. Patojenite testinde kullanılan konidi süspansiyonunu hazırlamak için, tek spordan elde edilmiş fungal izolatın (GCP19MKU) kültürü içeren petri kabına steril saf su eklenerek ve miselyum yüzeyinden steril spatula yardımı ile kazıma yapılarak konidi süspansiyonu hazırlanmıştır. Konidi süspansiyonu, sporları miselyal parçalardan ayırmak için 2 katlı tülbent yardımı ile süzülmüştür. Elde edilen konidi süspansiyonu, hemositometre yardımı ile hesaplanarak $1 \times 10^{5}$ konidi $\mathrm{ml}^{-1}$ konsantrasyona ayarlanmıştır. Patates yumruları uygulama yapılmadan önce, çeşme suyu ile yıkanıp \%2'lik $\mathrm{NaOCl}$ çözeltisi ile 2 dakika yüzeyde steril edilmiş, steril saf su ile 2 kez durulanmış ve yaralanmadan önce yumrular kurutma kağıdı üzerinde fan altında kurutulmuştur. Daha sonra yıkanıp kurutulan bu yumrulara, ekvatoral bölgede yumru üzerinde eşit açılarla üç farklı noktadan $2 \mathrm{~mm}$ derinliğinde $5 \mathrm{~mm}$ çapında bir yara oluşturmak için steril bir mantar delici yardımı ile yaralar açılmıştır. Yaralanmış yumrulara, $1 \times 10^{5}$ konidi $\mathrm{ml}^{-1}$ konsantrasyonunda hazırlanmış olan $20 \mathrm{ml}$ hacmindeki spor süspansiyonu spreyle püskürtülerek inokulasyon gerçekleştirilmiştir (Hameed ve ark., 2019). Kontrol olarak, sadece steril saf su ile muamele edilmişs yumrular kullanılmıştır. İnokulasyon sonrası yumrular zemini steril su ile ıslatılmış kağıt havluların bulunduğu 20×20x10 cm ebadında plastik şeffaf saklama kutularına yerleştirildikten sonra, 20 ${ }^{\circ} \mathrm{C}, \% 85$ bağ $1 \mathrm{l}$ nem ve $12 \mathrm{~h}$ fotoperiyot koşullarına ayarlı inkübatörler içerisinde inkübasyona bırakılmışlardır. Yapay olarak enfektelenmiş yumrulardan hastalık gelişimi inokulasyondan 7 gün sonra değerlendirilmiştir.

\section{MALDI-TOF MS Analizi}

Doğal olarak enfekteli yumrulardan elde edilen ve patojenisite çalışmalarında hastalık belirtilerine neden olan izolatların tür teşhisleri, Hatay Mustafa Kemal Üniversitesi Bitki Sağlığı Kliniği Uygulama ve Araştırma Merkezi'nde bulunan MALDI-TOF MS (Matrix Assisted Laser Desorption Ionization- Time of Flight Mass Spectrometry, Bruker Daltonics GmbH, Bremen, Almanya) Mikroorganizma Tanımlama cihazı kullanılarak tanılanmıştır (Kara ve ark., 2017; Soylu ve ark., 2020). Bu aşamada saf fungus kültürlerinden protein izolasyonu, etanol-formik asit ekstraksiyon yöntemi kullanılarak yapılmıştır. Cihazın flex kontrol yazılım programı (Biotyper 3.0; Microflex LT; Bruker
Daltonics GmbH, Bremen, Germany) ile elde edilen spektrumlar, Maldi Biotyper Real-Time Classification (RTC) yazılımı ile karşılaştırılarak tanı işlemi sürdürülmüştür. Analiz sonucunda, 2.000-3.000 arasında yeşil renkli olarak belirlenen veriler, yüksek güvenilirliğe sahip skor değeri olarak kabul edilmiştir (Carolis ve ark., 2012; Chalupová ve ark., 2014).

\section{Moleküler Karakterizasyon}

Morfolojik ve MALDI-TOF yöntemi kullanılarak ön teşhisleri yapılmış bölge ve patojenite testinden geri elde edilen fungal izolatların besi ortamında gelişen tek spor kültürlerinden alınan misellerinden (100 mg) toplam genomik DNA izolasyonu DNeasy Plant Mini Kiti (Qiagen, GeneMark Teknoloji Co, Valencia, CA, Katalog No. 69104) ile üretici firmanın önerdiği protokollerin uygulanması suretiyle yapılmıştır. PCR çalışmaları Internal transcribed spacers (ITS) ITS1 (5'TCCGTAGGTGAACCTGCGG- $\left.3^{\prime}\right)$ ve ITS4 (5'TCCTCCGCTTATTGATATGC-3') primer çifti (White ve ark., 1990) kullanılmak suretiyle gerçekleştirilmiştir. PCR çalışmasında her bir reaksiyon için $1 \times$ enzim buffer, $0.2 \mu \mathrm{l}$ dNTP, $0.5 \mu \mathrm{l}$ primer, $1.5 \mu \mathrm{l} \mathrm{MgCl}$, $0.2 \mu \mathrm{l}$ (ng) DNA, toplam $25 \mu \mathrm{l}$ olacak şekilde üzeri steril saf su ile tamamlanmıştır. DNA amplifikasyonu Thermal cycler PCR cihazında (Applied Biosystems, Singapore) yapılmıştır. PCR amplifikasyon koşulları için, $95^{\circ} \mathrm{C}$ de $1 \mathrm{dk}$. başlangıç denatürasyonu, $95^{\circ} \mathrm{C}$ 'de 20 sn. denatürasyon, annealing sicaklığ $55^{\circ} \mathrm{C}$ 'de 25 sn., $72^{\circ} \mathrm{C}$ 'de $1 \mathrm{dk}$. ve final adımı olarak $72^{\circ} \mathrm{C}^{\prime} \mathrm{de} 10 \mathrm{dk}$. olarak belirlenmiştir. PCR ürünlerinin kalitesini belirlemek için Kapiler jel elektroforez cihazı kullanılmıştır (QIAxcel Advanced, Qiagen, Almanya). Bantların kalitesine göre PCR ürünü sekanslanmıştır. Sekans sonuçları BLAST programına yüklenerek fungus türü belirlenmiştir. PCR ürününe ait DNA nükleotid dizisi, NCBI (National Center for Biotechnology Information) kütüphanesinde yer alan BLASTn algoritmasinı kullanarak (Boratyn ve ark., 2013) gerçekleştirilmiştir. Bu sonuçlara göre tanısı yapılan izolatın, NCBI Gen Bankası kütüphanesinden erişim numarası alınmıştır. G. candidum GCP19MKU izolatını, farklı konukçu bitkilerden elde edilen referans izolatlarla karşılaştırmak için (Çizelge 1), MEGA 7 programını kullanarak ITS gen bölgesi için akrabalık derecelerine göre moleküler filogenetik analizleri gerçekleştirilmiştir. İzolatlar arasındaki genetik akrabalığ gösteren dendrogram UPGMA (unweighted pair group method with arithmetic mean) yöntemi kullanılarak oluşturulmuş ve elde edilen filogenetik ağacın teyidi, 1,000 tekrarlı olarak (Bootstrap, p-distance, pairwise deletion) yapılmıştır (Kumar ve ark., 2016).

\section{BULGULAR ve TARTIŞMA}

Hastalık Etmeninin İzolasyonu, Morfolojik ve 
Patojenik Özelliklerinin Belirlenmesi

Konya ilinin Çumra ilçesinde patates yetiştirilen tarlalarda 2019 yılının Temmuz ayında gerçekleştirilen sörveyler sırasında ekşi koku yayan patates yumruları yüzeyinde iç dokuya kadar ilerleyen suya batırılmış yumuşak çürüklük lezyonları ve bu lezyonların yüzeyinde kabarık beyaz miselyum ile kaplanmış yeni bir hastalık belirtileri gözlenmiştir.

Çizelge 1. NCBI veri tabanından alınarak filogenetik analizlerde kullanılan $G$. candidum referans izolatlara ait konukçu bitki, izole edildiği ülke ve GenBankası erişim kayıtları

Table 1. Host plant, location and GenBank accession numbers of G. candidum isolates registered in NCBI database used in phylogenetic analysis

\begin{tabular}{ccccc}
\hline $\begin{array}{c}\text { Tür } \\
\text { Species) }\end{array}$ & $\begin{array}{c}\text { Izolat No. } \\
\text { (Isolate No.) }\end{array}$ & $\begin{array}{c}\text { Konukçu Türü } \\
\text { (Host species) }\end{array}$ & $\begin{array}{c}\text { Menşei } \\
\text { (Origin) }\end{array}$ & $\begin{array}{c}\text { GenBank Erişim No. } \\
\text { (GenBank Accssion No.) }\end{array}$ \\
\hline Geotrichum candidum & GCP19MKU & Patates & Türkiye & MN621396 \\
Geotrichum candidum & T5.01 & Toprak & Brezilya & MK943787 \\
Geotrichum candidum & UCDFST:09-582 & Muz & ABD & MH153550 \\
Geotrichum candidum & S001 & Dut & Çin & KY486783 \\
Geotrichum candidum & GC111 & Şeker pancarı & ABD & MK436200 \\
Geotrichum candidum & GC222 & Şeker pancarı & ABD & MK436202 \\
Geotrichum candidum & PD10019 & Şeftali & Pakistan & KY495323 \\
Geotrichum candidum & PD2018 & Havuç & Pakistan & MH729185 \\
Geotrichum candidum & PD2018B & Havuç & Pakistan & MK215811 \\
Geotrichum candidum & UoS001 & Meyve & Pakistan & KF975700 \\
Geotrichum candidum & ET 13 & Havuç & Türkiye & Kayitll Değil \\
Geotrichum citri-aurantii & MKUGCA2 & Turunçgil & Türkiye & Kayıtlı Değil \\
\hline
\end{tabular}
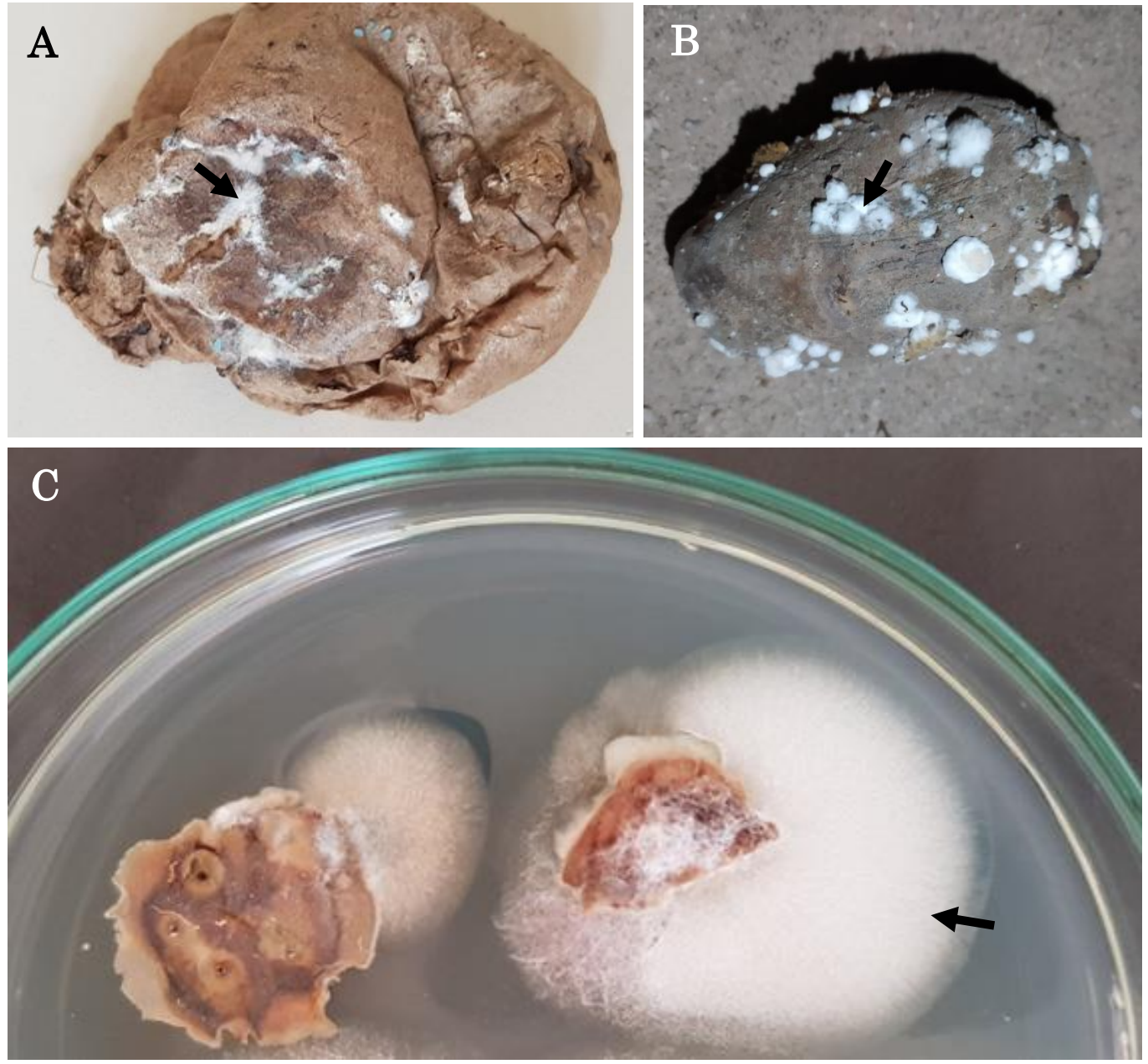

Şekil 1. (A ve B) Patates yumrularında Geotrichum candidum enfeksiyonlarının neden olduğu tipik hastalık belirtileri ve beyaz misel kitleleri (ok). (C) Enfekteli dokulardan gelişen $G$. candidum izolatının misel gelişimi (ok).

Figure 1. (A and B) Typical disease symptoms and white mycelial masses caused by Geotrichum candidum infections in 


\section{potato tubers (ok). Mycelial growth of $G$. candidum isolate developing from infected tissues (arrow).}

Tipik hastalık belirtilerin gözlendiği yumrulardan (Şekil 1A,B) Patates Dekstroz Agar besiyeri üzerinde hızlı büyüyen düz, beyaz ve süet-tozlu görünümlü pigmentsiz fungal koloniler gelişmiştir (Şekil 1C, Şekil 2A). Gelişen kolonilerin miselyumları 2.5-6.0 $\mu \mathrm{m}$ çapında, dichotomous olarak dallanmış, şeffaf ve bölmeli yapıdadır. Dichotomous dallanma gösteren hiflerden, 4.5-12.5 $\times$ 3.5-7.0 $\mu \mathrm{m}$ boyutlarda, tek hücreli havai uzun zincir şeklinde sıralanmış şeffaf, uçları kesik ve silindirik yapıda artrokonidilerin geliştiği gözlenmiştir (Şekil 2B). Konidiler genelde uçtan çimlenme göstermişlerdir. Hastalıklı bitki örneklerinden yapılan izolasyonlar sonucunda PDA besi yeri üzerinde gelişen tipik izolatlardan tek spor izolatları elde edilmiştir (Şekil 2A).

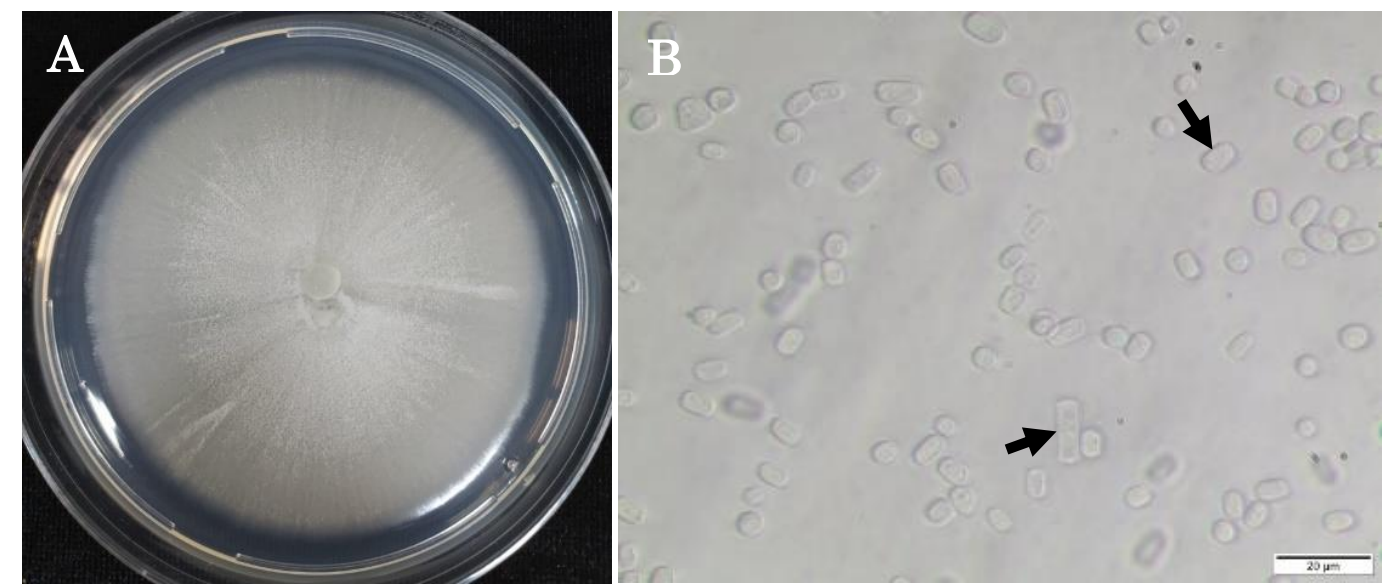

Şekil 2. (A) Hastalıklı dokulardan izole edilmişs saf tek spor Geotrichum candidum MKUBK-GCP19 izolatının PDA besiyerinde 5 günlük misel gelişimi. (B) $G$. candidum izolatına ait tipik artrokonidileri (ok)

Figure 2. (A) Mycelial development of pure single spore culture of Geotrichum candidum MKUBK-GCP19 isolate obtained from diseased tissues at the PDA medium 5 days after inoculation. (B) Typical arthroconidia of $G$. candidum isolate.

Fungus izolatının hif ve konidilerinin morfolojik ve taksonomik karakterlerine dayanarak etmen, Geotrichum candidum Link 1809 (Syn. Galactomyces geotrichum) olarak tanımlanmıştır (de Hoog ve ark., 1986; Watanabe, 2010). Etmenin sağlıkl patates yumruları üzerinde yapılan patojenite testi sonucunda, patates yumrularındaki inokulasyon noktalarında tarla örneklerinde görülen lastik çürüklük hastalık belirtilerine benzer lezyonlar inokulasyondan 7 gün sonra gelişmiştir. Hastalık etmeni yapay olarak inokulasyon yapılmış dokulardan geri izole edilmiştir. Fungusun patojenite testinde kullanılan ve geri elde edilen re-izolatların tek spor kültürleri Hatay Mustafa Kemal Üniversitesi, Bitki Sağlığı Kliniği Kültür Koleksiyon Merkezi’nde koruma altına alınmıştır (Kayıt numarası: MKUBK-GCP19).

\section{MALDI-TOF MS Analizi}

Mikroorganzimaların tanılanmasında kullanılan yeni nesil yöntemlerinden biri olan Matrix Assisted Laser Desorption Ionization-Time of Flight Mass Spectrometry (MALDI-TOF MS), proteomik yaklaşım ile özellikle bitki patolojisinde fungal ve bakteriyel mikrobiyal türlerin tanılamasında, kromatografik ve DNA'ya bağlı moleküler yöntemlere alternatif olarak kullanımı gittikçe yaygınlaşmaktadır (Pulcrano ve ark., 2012; Aktan ve Soylu, 2020; Bozkurt ve ark., 2020). Gerek doğal enfekteli yumrulardan elde edilen, gerekse patojenite testinden yeniden izole edilen (reizolat) G. candidum fungal izolatların tanısı MALDITOF MS analiziyle teyit edilmiştir. Yapılan analiz sonucunda fungal izolatlarm MALDI-TOF kütüphanesinde yer alan referans izolat $G$. candidum DSM 1240 ile 2.197 gibi yüksek benzerlik indeks değerinde eşleşmiştir (Şekil 3).

\section{Moleküler Karakterizasyon}

Gerek morfolojik, gerekse MALDI-TOF ile tanılaması yapılmış patojenite testinde belirtilere neden olmuş $G$. candidum GCP19MKU izolatın kesin tür tanısı, izolatın ITS bölgesini sekanslama yapmak suretiyle moleküler düzeyde belirlenmiştir. Ribozomal DNA'nın internal transcribed spacer (ITS) bölgesinin amplikonları, evrensel ITS1 ve ITS4 primerleri kullanarak PCR ile çoğaltılmıştır. Elde edilen izolatın genomik DNA gen dizileri, \%99 benzerlikle dünyanın farklı bölgelerinde farklı konukçu bitkilerden izole edilmiş $G$. candidum izolatlarının GenBank'taki DNA dizileri (erişim numaraları MK943787, MH153550, MK436202) ile eşleştiği belirlenmiş olup, analizde kullanılan patates izolatının (GCP19MKU) genomik DNA dizisi GenBank'a kayıt edilmiştir [GenBank erişim No: MN621396]. Gerek bu çalışmada elde edilen, gerekse NCBI kayıtlı farklı konukçu bitkilerden/kaynaklardan elde edilmiş $G$. candidum ve yakın akraba $G$. citri-aurantii izolatların nükleotid dizileri (Çizelge 1), UPGMA yöntemi kullanılarak 
MEGA 7 yazılımı ile ITS gen bölgesi için filogenetik dendrogramı elde edilmiştir (Şekil 4). Bu dendrograma göre patateste lastik çürüklük hastalığına neden olan G. candidum GCP19MKU izolatı toprak kökenli ve muz meyvesinde ekşi çürüklük hastalığına neden olan G. Candidum UCDFST:09-582 ve T5.01 izolatları (MK943787 ve MH153550) ile aynı alt grupta yer ayrılmıştır.

\begin{tabular}{|c|c|c|c|c|}
\hline Analyte1 & & [ & ker* Lo & \\
\hline $\begin{array}{l}\text { Analyte Nar } \\
\text { Analyte Des } \\
\text { Analyte ID: } \\
\text { Analyte Cre } \\
\text { Applied MS } \\
\text { Applied Tax }\end{array}$ & $\begin{array}{l}\text { : } \\
\text { ate/Time: } \\
\text { y(ies): } \\
\text { Tree: }\end{array}$ & $\begin{array}{l}\text { E1 } \\
\text { Patates 19 } \\
\text { 2018-10-01T12:18:10.486 } \\
\text { Taxonomy, Bruker Taxonomy }\end{array}$ & & \\
\hline $\begin{array}{c}\text { Rank } \\
\text { (Quality) }\end{array}$ & & Matched Pattern & $\begin{array}{l}\text { Scare } \\
\text { Value }\end{array}$ & $\begin{array}{c}\text { NCBI } \\
\text { Identifier }\end{array}$ \\
\hline $\begin{array}{c}1 \\
(++)\end{array}$ & Geotricl & m candidum DSM 1240 DSM & 2.197 & 27317 \\
\hline $\begin{array}{c}2 \\
(++)\end{array}$ & Geoti & hum silvicola 04322 LBK & 2.072 & $\underline{215419}$ \\
\hline $\begin{array}{l}3 \\
(+)\end{array}$ & Geots & hum silvicola 04_007 LBK & 1.94 & $\underline{215419}$ \\
\hline $\begin{array}{c}4 \\
(+)\end{array}$ & Geoti & hum silvicola 04 188 LBK & 1.907 & $\underline{215419}$ \\
\hline$\left(\begin{array}{c}5 \\
(-)\end{array}\right.$ & Geotrich & $n$ candidum CBS $18456 \mathrm{CBS}$ & 1.662 & $\underline{27317}$ \\
\hline
\end{tabular}

Şekil 3. Hastalıklı patates yumrusundan izole edilen ve patojenite testinde kullanılan G. candidum MKUBKGCP19 izolatının MALDI-TOF teşhis sonucu.

Figure 3. MALDI-TOF identification result of G. candidum $M K U B K^{-} G C P 19$, isolated from the diseased potato tuber and used in the pathogenicity test.

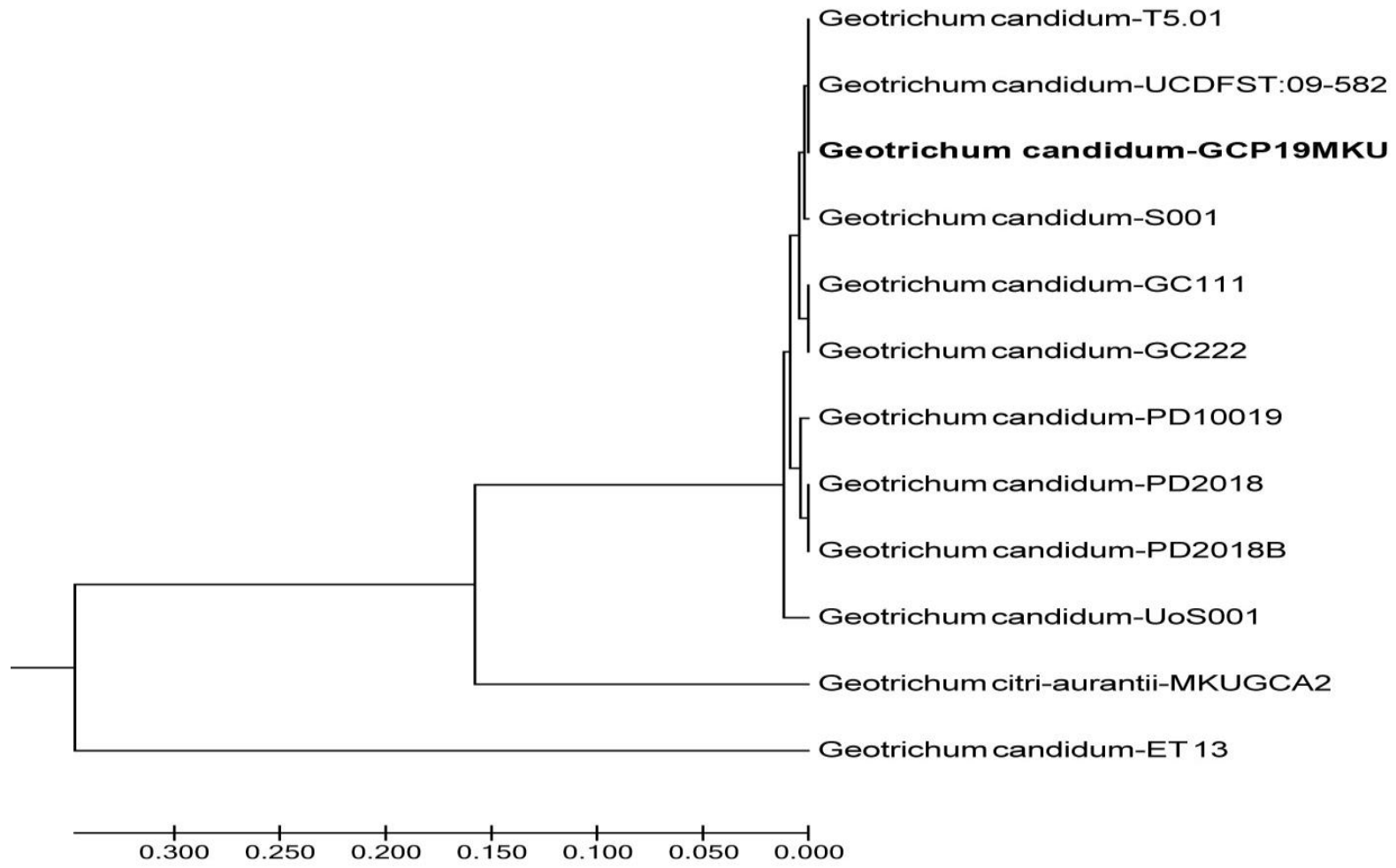

SSekil 4. G. candidum GCP19MKU izolatı ile GenBank'tan alınan farklı G. candidum izolatlarının nükleotit sekanslarının dizilerine dayanılarak oluşturulan izolatlar arasındaki filogenetik ilişki. Filogenetik dendrogram, MEGA 7.0 programı kullanılarak UPGMA yöntemi ile oluşturulmuştur.

Figure 4. Phylogenetic relationship between G. candidum GCP19MKU and reference isolates of G. candidum retrieved from GenBank based on alignment of nucleotide sequences. The tree was constructed by the UPGMA method using MEGA version 7.0. 
Türkiye'de şimdiye kadar $G$. candidum'un sebep olduğu ekşi çürüklük hastalığı havuç meyvelerinde bildirilmiştir (Tülek ve Dolar, 2011; Tozlu, 2016). Filogenetik analiz sonucunda oluşan dendogramda (Şekil 4) görüleceği gibi Tozlu (2016) tarafından Türkiye'de yetişen havuç meyvelerinden izole edilip moleküler karekterizasyonu yapılmıs ancak NCBI kayıdı olmayan G. candidum ET13 izolat ile etmeninin yakın akraba türü olan ve Hatay ilinde yetiştirilen turunçgillerde ekşi çürüklük hastalığına neden olan Geotrichum citri-aurantii MKUGCA2 izolatlarının (Kara ve Soylu, 2020) patatesten izole edilen $G$. candidum GCP19MKU izolatına kıyasla dış grupta yer almıştır. Elde edilen filogenetik çalışma sonucuna göre, havuç ve turunçgil izolatlarının patates izolatından farklı bir genetik yapıya sahip olduğu belirlenmiştir (Şekil 4).

Yapılan morfo-kültürel, patojenite denemeleri ve moleküler analizler sonucu Konya ili Çumra ilçesinde yetiştirilen patates yumrularında lastik çürüklüğü hastalığına neden olan fungal etmenin $G$. candidum olduğu kesinlik kazanmıştır. Toprak kökenli hastalık etmeni olan G. candidum, aynı zamanda depolanmış ürünlerde de sorun olan önemli bir fungal etmendir. Etmenin depolanmış ürünlerdeki hastalığı genelde ekşi çürüklük olarak adlandırılmaktadır. Hastalık etmenin şeftali, elma, armut, domates, patlıcan, hıyar, dut, havuç, kabak ve turp gibi bitkilerin meyvelerini enfekte edebildiği bilinmektedir (Koike ve ark., 2007; Kim ve ark., 2011; Hafeez, ve ark., 2015; Hussain ve ark., 2016; Horita ve Hatta, 2016; Punja ve ark., 2016; Alam ve ark., 2017; Zhang ve ark., 2018; Kahn ve ark., 2019.

Türkiye'de şimdiye kadar G. candidum'un sebep olduğu ekşi çürüklük hastalığı havuç meyvelerinde bildirilmiştir (Tülek ve Dolar, 2011; Tozlu, 2016). Yapılan kapsamlı literatür araştırmasında (Farr ve Rossman, 2020), Türkiye'de yetiştiriciliği yapılan patates yumrularında lastik çürüklüğü hastalığından sorumlu fungal hastalık etmeni olduğu ilk kez bu çalışma ile ortaya konulmuştur. Fungal etmenin patates bitkisinde hastalığa neden olduğu bugüne kadar sadece Papua Yeni Guinea (Shaw, 1984) ve Güney Kore (Kim ve ark., 2011) ülkelerinde bildirilmiştir.

\section{SONUÇ ve ÖNERILER}

Sonuç olarak, bazı ülkelerde patates bitkilerinde hastalığa neden olduğu bildirilen $G$. candidum'un Türkiye'de varlığı bazı sebzelerde ekşi çürüklük hastalığına neden olduğu bildirilmiş olmakla birlikte, patates yumrularında sebep olduğu lastik çürüklük hastalığı ilk kez bu çalışma ile ortaya konulmuştur. Etmenin geniş bir konukçu dizisinin bulunması, güçlü patojenitesi ve çeşitli ürünlerde hastalığın ortaya çıkması, patates üretiminde ciddi bir tehdit oluşturabileceğini ortaya koymaktadır.

\section{TEŞEKKÜR}

$\mathrm{Bu}$ çalışma Osman TOKETTİ'nin yüksek lisans çalışmasının bir kısmını kapsamakta olup, Hatay Mustafa Kemal Üniversitesi Bilimsel Araştırma Projeleri Komisyonu Başkanlığ olarak desteklenmiştir (Proje Numarası: MKU BAP18.YL.081).

\section{Araştırmacıların Katkı Oranı Beyan Özeti}

Yazarlar makaleye eşit oranda katkı sağlamış olduklarını beyan eder.

\section{Çıkar Çatışması Beyanı}

Makale yazarları aralarında herhangi bir çıkar çatışması olmadığını beyan ederler.

\section{KAYNAKLAR}

Aktan ZC, Soylu S 2020. Diyarbakır İlinde Yetişen Badem Ağaçlarından Endofit ve Epifit Bakteri Türlerinin İzolasyonu ve Bitki Gelişimini Teşvik Eden Mekanizmalarının Karakterizasyonu. KSU Tarım ve Doğa Dergisi 23 (3): 641-654.

Alam MW, Rehman A, Malik AU, Iqbal Z, Amin M, Ali S, Hameed A, Sarfraz S 2017. First Report of Geotrichum candidum Causing Postharvest Sour Rot of Peach in Punjab, Pakistan. Plant Disease 101(8): 1543-1544.

Anonim 2017. TUİK Bitkisel Üretim İstatistikleri. https://biruni.tuik.gov.tr/medas/?kn=92\&locale $=$ tr (Erişim Tarihi: 21.02.2020)

Anonymous, 2017. FAOSTAT, World Production Quantities of Crops http://www.fao.org (Erişim tarihi: 21.02.2020).

Aydın M.H, Pala F, Kaplan C 2016. Potato Tuber Sprout Rot Caused by Fusarium sambucinum in Turkey. Scientific Papers - Series A Agronomy 59: 189-193.

Boratyn GM, Camacho C, Cooper PS, Coulouris G, Fong A, Ma N, Madden TL, Matten WT, McGinnis SD, Merezhuk Y, Raytselis Y, Sayers EW, Tao T, Ye J, Zaretskaya I 2013. BLAST: A More Efficient Report with Usability Improvements. Nucleic Acids Research 41: 29-33.

Bozkurt IA, Soylu S, Kara M, Soylu EM 2020. Chemical Composition and Antibacterial Activity of Essential Oils Isolated from Medicinal Plants against Gall Forming Plant Pathogenic Bacterial Disease Agents. KSU Tarım ve Doğa Dergisi 23 (6): 1474-1482.

Çakır E 2005. First Report of Potato Wart Disease in Turkey. Plant Pathology 54: 584.

Çakır E, Demirci F 2012. First Report of Phytophthora cryptogea on Potato Tubers in Turkey. Plant Disease 96: 1224-1225. 
Çakır E, Karahan A, Kurbetli İ 2019. Involvement of Colletotrichum coccodes Causing Atypical Symptoms of Potato Tubers in Turkey. Journal of Plant Diseases and Protection 126: 173-176.

Carolis ED, Posteraro B, Lass-Flo C, Vella A, Florio AR, Torelli R, Girmenia C, Colozza C, Tortorano AM, Sanguinetti M, Fadda G 2012. Species Identification of Aspergillus, Fusarium and Mucorales with Direct Surface Analysis by MatrixAssisted Laser Desorption Ionization Time-ofFlight Mass Spectrometry. Clinical Microbiology and Infection 18: 475-484.

Chalupová J, Raus M, Sedlářová M, Šebela M 2014. Identification of Fungal Microorganisms by MALDI-TOF Mass Spectrometry. Biotechnology Advances 32: 230-241.

De Hoog GS, Smith MT, Gueho E 1986. A Revision of the Genus Geotrichum and Its Teleomorphs. Studies in Mycology 29: 1-131.

Eken C, Demirci E, Şahin F 2000. Pathogenicity of the Fungi Determined on Tubers from Potato Storages in Erzurum. Journal of Turkish Phytopathology 29: 61-69.

Ezekiel R, Singh N, Sharma S, Kaur A 2013. Beneficial Phytochemicals in Potato - A Review. Food Research International 50: 487-496.

Farr DF, Rossman AY 2020. Fungal Databases. Systematic Mycology and Microbiology Laboratory, USDA ARS. Retrieved from http://nt.arsgrin.gov/fungaldatabases/ (Erişim Tarihi: 21.02.2020)

Gore ME, Senkal BC, Berk SK, Onaran H, Altin N, Ay E, Tuna S, Zencirci N 2015. Recovery of Verticillium dahliae from Commercially Available Potato Seed Lots Planted in Turkey and Characterization of Isolates by Vegetative Compatibility and Aggressiveness. Phytoparasitica 43: 241-251.

Hafeez R, Akhtar N, Shoaib A, Bashir U, Haidar MS, Awan ZA 2015. First Report of Geotrichum candidum from Pakistan Causing Postharvest Sour Rot in Loquat (Eriobotrya japonica). The Journal of Animal \& Plant Sciences 25(6): 1737-1740.

Hameed A, Alam MW, Rehman A, Naveed K, Atiq M, Rajput NA, Sarfraz S, Liaqat N, Tahir FA 2019. First Report of Geotrichum candidum Causing Postharvest Sour Rot of Carrot in Punjab, Pakistan. Journal of Plant Pathology 101(3): 763.

Horita H, Hatta Y 2016. Sour Rot of Carrot Caused by Geotrichum candidum in Japan. Journal of General Plant Pathology 82: 65-68.

Hussain M, Hamid MI, Ghazanfar MU, Akhtar N, Raza M 2016. First Report of Fruit Rot of Strawberry Caused by Geotrichum candidum in Pakistan. Plant Disease 100(9): 1948-1949.

Kahn MFR, Haque ME, Brueggeman R, Zhong S, Bhuiyan MZR, Poudel RS, Gross T, Hakk P, Liu Y, 2019. First Report of Geotrichum candidum Causing Postharvest Rot of Sugar Beet (Beta vulgaris) Roots in Minnesota and North Dakota. Plant Disease 103(12): 3278.

Kara M, Uysal A, Soylu S, Kurt Ş, Soylu, EM 2017. Identification of Plant-Associated Microorganisms Employing MALDI TOF Mass Spectrometry as a Rapid Detection Technique. International Conference on Agriculture, Forest, Food Sciences and Technologies (ICAFOF), 15-17 May, 2017. Nevşehir, p. 1111.

Kara M, Soylu EM 2020. Assessment of GlucosinolateDerived Isothiocyanates as Potential Natural Antifungal Compounds Against Citrus Sour Rot Disease Agent Geotrichum citri-aurantii. Journal of Phytopathology 168(5): 279-289.

Kim YK, Kim TS, Shim HS, Park KS, Yeh WH, Hong SJ, Shim CK, Kim JS, Park JH, Han EJ, Lee MH, Jee HJ 2011. First Report of Sour Rot on PostHarvest Oriental Melon, Tomato, Cucumber, Potato, Pumpkin and Carrot Caused by Geotrichum candidum. Research in Plant Disease 17(2): 232234.

Koike ST, Gladders P, Paulus, AO 2007. Vegetable Diseases: A Colour Handbook. Manson Publishing, London, pp. 95-115.

Kumar S, Stecher G, Tamura K 2016. MEGA7: Molecular Evolutionary Genetics Analysis Version 7.0 for Bigger Datasets. Molecular Evolutionary Genetics Analysis 33(7): 1870-1874.

Kurt Ş, Uysal A, Kara M, Soylu S, Soylu EM 2017. Natural Infection of Potato by Sclerotinia sclerotiorum Causing Stem Rot Disease in Turkey. Australasian Plant Disease Notes 12: 39.

Ozer G, Bayraktar H, Tsror L, Yaman T, Kabakci H, Gore ME 2018. Vegetative Compatibility Groups in Colletotrichum coccodes from Turkey and Their Aggressiveness to Potato. Plant Pathology 67: 17351739.

Pulcrano G, Roscetto E, Iula VD, Panellis D, Rossano F, Catania MR 2012. MALDI-TOF Mass Spectrometry and Microsatellite Markers to Evaluate Candida parapsilosis Transmission In Neonatal Intensive Care Units. European Journal of Clinical Microbiology \& Infectious Diseases 31: 2919-2928.

Punja ZK, Rodriguez G, Tirajoh A, Formby S 2016. Role of Fruit Surface Mycoflora, Wounding and Storage Conditions on Post-Harvest Disease Development on Greenhouse Tomatoes. Canadian Journal of Plant Pathology 38(4): 448-459.

Shaw DE 1984. Microorganisms in Papua New Guinea. Research Bulletin of the Department of Primary Industries Port Moresby 33: 1-344. (6277)

Soylu EM, Soylu S, Kara M, Kurt Ş 2020. Sebzelerde Sorun Olan Önemli Bitki Fungal Hastalık Etmenlerine Karşı Vermikomposttan Izole Edilen Mikrobiyomların in vitro Antagonistik Etkilerinin Belirlenmesi. KSU Tarım ve Doğa Dergisi 23(1): 718. 
Tozlu E 2016. Bazı Bakteriyel Biyokontrol Ajanlar ile Havuç Acı Çürüklük Hastalığı (Geotrichum candidum Link)'nın Biyolojik Mücadelesi. Atatürk Üniversitesi Ziraat Fakültesi Dergisi 47 (1): 1-9.

Tülek S, Dolar FS, 2011. Havuçlarda Görülen Depo Hastalıkları ve Yönetimi. GOÜ Ziraat Fakültesi Dergisi 28(2): 187-198.

Watanabe T 2010. Pictorial Atlas of Soil and Seed Fungi: Morphologies of Cultured Fungi and Key to Species, 3rd Ed. CRC Press, Boca Raton, FL. 426 pp.

White TJ, Bruns T, Lee S, Taylor J 1990. Amplification and Direct Sequencing of Fungal Ribosomal RNA Genes for Phylogenetics. In: PCR Protocols: A Guide to Methods and Applications, Innis MA, Gelfand
DH, Sninsky JJ, White TJ (eds). Academic Press, San Diego, pp. 315-322.

Yanar Y, Yilmaz G, Cesmeli I, Coskun S 2005. Characterization of Rhizoctonia solani Isolates from Potatoes in Turkey and Screening Potato Cultivars for Resistance to AG-3 Isolates. Phytoparasitica 33: 370-376.

Zhang H, Xu F, Hu HH, Dai XF 2017. Progress of Potato Staple Food Research and Industry Development in China. Journal of Integrative Agriculture 16(12): 2924-2932.

Zhang L, Li YH, Zhang XM, Zhang QH, Xian HQ 2018. First Report of Sour Rot Caused by Geotrichum candidum on Mori fructus in China. Plant Disease 102(12): 2640-2641. 